\title{
Efektivitas Penggunaan Modul Numerasi Pada Pembelajaran Jarak Jauh
}

\author{
Rahayu Lestari ${ }^{1)}$, Rahma Faelasofi' ${ }^{2)}$, Suminto ${ }^{3)}$ \\ 1),2),3)Universitas Muhammadiyah Pringsewu Lampung ${ }^{1}$ \\ email: rahmafaelasofi@umpri.ac.id
}

\begin{abstract}
This study aims to determine the effectiveness the numeracy module during of the distance learning in terms of learning outcomes, activities, responses, and learning implementation. The problem in grade IV SDI Ma'arif 02 Terbanggi Besar is that there are no teaching materials that are adapted for distance learning so that the learning process of mathematics (numeracy) is hampered. This research is a pre-experimental research with the design of the one shot case study where there is one class that is given treatment and then the measurement is carried out to find out the results. The results of the research were: (1) There were $87.5 \%$ of the total students who achieved the KKM learning outcomes; (2) The average percentage of student activity is 87.5\%; (3) The percentage of student responses was $93.38 \%$ of students gave positive responses; (4) The results of observations of the implementation of learning obtained an average score of 3.65. Based on the results of research and discussion, it can be concluded that using the numeration module during of the distance learning was effectively applied in class IV SDI Ma'arif 02 Terbanggi Besar on the theory of rectangular area.
\end{abstract}

Keywords: Effectiveness, Distance Learning, Numeration Module

\section{PENDAHULUAN}

Pandemi covid-19 berdampak pada seluruh bidang terutama pada bidang pendidikan yaitu pelaksanaan pembelajaran secara daring mulai dari jenjang pendidikan dasar sampai pendidikan tinggi. Hal itupun berdampak pada pembelajaran di jenjang sekolah dasar yang dilakukan secara jarak jauh. Berdasarkan Undang-Undang Republik Indonesia Nomor 20 Tahun 2003 tentang Sistem Pendidikan Nasional pasal 1 ayat 15 yang menyatakan bahwa pendidikan jarak jauh adalah pendidikan yang peserta didiknya terpisah dari pendidik dan pembelajarannya menggunakan berbagai sumber belajar melalui teknologi komunikasi, informasi dan media lain. Dalam masa darurat yang menuntut adaptasi pembelajaran, keterbatasan sumber daya dan kendala teknis berdampak pada kemungkinan pembelajaran tidak tersampaikan secara utuh, sehingga pembelajaran jarak jauh tidak dapat terlaksana secara efektif.

Berdasarkan hasil wawancara yang penulis lakukan dengan ibu Ida Andhayani, S.Sos. selaku guru kelas IV SD Islam Ma'arif 2 Terbanggi Besar. Beliau menyatakan bahwa pembelajaran daring yang dilakukan selama ini menggunakan WhatsApp grup. Kegiatan pembelajaran yang dilakukan hanya sebatas penugasan yang dikumpulkan oleh siswa setiap satu minggu sekali. Namun masih banyak siswa yang tidak mengerjakan tugas yang diberikan oleh guru. Bahan ajar yang digunakan yaitu buku tema kelas IV kurikulum 2013 dan buku matematika kelas IV yang belum disederhanakan atau dikhususkan untuk 
pembelajaran jarak jauh. Sehingga siswa merasa kesulitan dalam mengerjakan tugas-tugasnya dan orang tua juga tidak bisa mendampingi anaknya dalam belajar dari rumah karena kurang memahami materi yang dipelajari oleh anaknya terutama pada pembelajaran matematika. Sehingga siswa tidak bisa melakukan aktivitas pembelajaran secara optimal setiap hari dan respons siswa terhadap pembelajaran cenderung negatif, karena siswa merasa terbebani dengan tugas-tugas yang diberikan guru serta kurang dapat memahami apa yang telah dipelajari melalui tugas tersebut sehingga hasil belajar yang diperoleh siswa masih rendah yaitu terdapat $56 \%$ dari jumlah siswa kelas IV yang memperoleh hasil belajar dibawah KKM sebesar 55. Sehingga pembelajaran jarak jauh yang dilakukan di kelas IV SD Islam Ma'arif 02 Terbanggi Besar belum efektif.

E. Mulyasa dkk (2016) menyatakan efektivitas adalah adanya kesesuaian antara orang yang melaksanakan tugas dengan sasaran yang dituju. Dengan demikian efektivitas merupakan keberhasilan yang diperoleh dari suatu kegiatan atau perlakuan. Selanjutnya menurut Uno dan Nurdin Muhammad (2014) pada dasarnya efektivitas ditujukan untuk menjawab pertanyaan seberapa jauh tujuan pembelajaran telah dapat dicapai oleh peserta didik. Sehingga dapat disimpulkan bahwa efektivitas pembelajaran merupakan keberhasilan dari suatu pembelajaran sehingga peserta didik dapat mencapai tujuan pembelajaran. Efektivitas pembelajaran dapat diketahui dengan melihat ketercapaian indikator keefektifan pembelajaran. Dimana menurut Wahyudin dan Nurcahaya (2018) terdapat empat indikator keefektifan pembelajaran meliputi : (1) Hasil belajar matematika siswa; (2) Aktivitas siswa dalam proses pembelajaran matematika; (3) Keterlaksanaan pembelajaran; dan (4) Respons siswa terhadap proses pembelajaran.

Menurut Prawiradilaga \& Chaeruman (2018) "modul adalah materi ajar yang dipersiapkan untuk proses belajar mandiri". Hal ini senada dengan Najuah et al., (2020) yang menyatakan bahwa modul merupakan salah satu alat bantu pembelajaran yang dapat digunakan oleh peserta didik dalam proses pembelajaran. Melalui modul, siswa dapat melakukan pembelajaran secara mandiri dengan berpedoman pada unsur-unsur yang terdapat dalam modul. Berdasarkan pendapat beberapa ahli tersebut dapat disimpulkan bahwa modul adalah salah satu bahan ajar yang digunakan dalam proses pembelajaran secara mandiri.

Modul numerasi kelas IV terdiri atas lima kegiatan yaitu intuisi bilangan, konsep matematika, eksplorasi matematika, latihan, dan refleksi pembelajaran yang akan diuraikan sebagai berikut.

a. Intuisi Bilangan

Menurut Hadi (2015) intuisi bilangan atau number sense dapat diartikan sebagai berpikir fleksibel dan intuisi tentang bilangan yang terdiri dari empat komponen, yaitu menilai besaran bilangan, komputasi mental, estimasi, dan menilai kerasionalitasan hasil perhitungan yang diperoleh. Sehingga intiusi bilangan (number sense) adalah suatu kemampuan berpikir secara luwes dengan bilangan yang mencakup menilai besaran, komputasi mental, estimasi, dan menilai kewajaran hasil perhitungan. Kegiatan intuisi bilangan pada modul numerasi hari ke-1 yaitu peserta didik melakukan kegiatan membandingkan luas daerah dari dua bangun datar persegi panjang yang dilengkapi dengan 
ukuran yang berbeda-beda. Kegiatan ini terdiri atas lima pasang gambar yang harus diberi tanda lebih kecil $(<)$, sama dengan $(=)$ atau lebih besar $(>)$. Sehingga peserta didik dapat mengembangkan kemampuan dalam intuisi bilangan.

b. Konsep Matematika

Pada kegiatan ini penjelasan konsep dasar matematika yaitu luas persegi panjang disampaikan dengan menggunakan dukungan gambar visual dan disampaikan secara interaktif sesuai dengan konteks dari tema dan subtema yaitu tema 2: Ketahanan Pangan dan subtema 3: Pengawetan Makanan. Dalam kegiatan ini disajikan sebuah bacaan yang berjudul "Mari Berbagi Brownies" yang berisi tentang suatu konsep luas persegi panjang dan sesuai dengan tema 2: Ketahanan Pangan dan subtema 3: Pengawetan Makanan. Tujuan dari kegiatan ini adalah peserta didik dapat memahami konsep luas persegi panjang serta dapat mengaplikasikannya di dalam kehidupan sehari-hari.

c. Eksplorasi Matematika

Pada kegiatan eksplorasi matematika, orangtua dan peserta didik melakukan kegiatan bersama yang mengandung unsur matematika. Dalam kegiatan ini peserta didik akan bereksplorasi dengan matematika untuk membangun konsep matematika dan menyelesaikan masalah dan meningkatkan kemampuan aras tinggi (HOTS). Kegiatan eksplorasi matematika pada hari ke-1 dalam modul numerasi yaitu terdapat sebuah gambar jemuran ikan yang berbentuk persegi panjang kemudian peserta didik menemukan panjang dan lebar suatu persegi panjang dengan menghitung banyaknya ikan yang terdapat pada petak mendatar dan petak vertikal serta menghitung jumlah seluruh ikan yang terdapat pada gambar tersebut dan mengaitkannya dengan luas persegi panjang. Selanjutnya peserta didik dapat menyimpulkan rumus luas persegi panjang dan menemukan contoh makanan awetan atau kemasan yang berbentuk persegi panjang dan dapat menentukan luasnya.

Dengan melakukan kegiatan eksplorasi matematika peserta didik mampu mencapai tujuan pembelajaran dan menyelesaikan permasalahan terkait dengan konsep luas persegi panjang.

d. Latihan

Pada kegiatan latihan peserta didik menyelesaikan soal-soal matematika yang berhubungan dengan konsep luas persegi panjang dan melatih keterampilan matematika seara mandiri. Tujuan dari kegiatan latihan adalah untuk memperlancar (mastery) konsep luas persegi panjang yang sudah dipelajari dan diekplorasi pada kegiatan sebelumnya yaitu kegiatan konsep matematika dan kegiatan eksplorasi matematika. Dalam kegiatan latihan peserta didik melakukannya mandiri dengan lembar kerja yang disediakan maupun di buku kerja peserta didik. Selanjutnya hasil pekerjaan peserta didik akan di analsis menjadi skor hasil belajar yang dapat digunakan untuk melihat efektivitas dari pembelajaran yang telah dilaksanakan.

e. Refleksi Pembelajaran

Kegiatan pembelajaran diakhiri dengan mengisi lembar refleksi. Tujuan refleksi ini adalah untuk melihat kemajuan siswa dalam mencapai tujuan pembelajaran. Kegiatan refleksi ini juga untuk memperoleh respons siswa terhadap pembelajaran. Dimana siswa memberikan tanggapan atas kegiatan 
pembelajaran yang telah dilakukan serta menilai kemampuan dirinya dalam melakukan setiap kegiatan seperti kegiatan intuisi bilangan, kegiatan konsep matematika, kegiatan eksplorasi matematika, serta kegiatan latihan. Dalam kegiatan ini siswa dapat memilih tiga pilihan yaitu belum mampu, mampu dengan bantuan orangtua, dan mampu secara mandiri. Sehingga jawaban tersebut dapat dianalisis sebagai respons siswa terhadap pembelajaran dan sebagai masukan bagi guru untuk mengetahui dukungan yang harus diberikan kepada peserta didik dalam proses pembelajaran

Berdasarkan hasil survei yang dilakukan oleh Puslitjak et al. (2020) yaitu dengan adanya modul belajar literasi dan numerasi, dapat memberikan arahan pembelajaran yang lebih jelas dan menurunkan beban belajar siswa dalam proses pembelajaran jarak jauh di rumah, selain itu dapat meningkatkan partisipasi belajar siswa dan meningkatkan kualitas pembelajaran selama pandemi. Berdasarkan uraian di atas, modul numerasi digunakan dengan tujuan sebagai bahan ajar yang dapat digunakan dalam pembelajaran numerasi pada kelas 4 sekolah dasar yang dilakukan secara daring maupun luring.

Dengan menggunakan modul numerasi diharapkan pembelajaran numerasi yang di lakukan melalui pembelajaran jarak jauh pada masa pandemi covid-19 dapat terlaksana secara efektif, sehingga siswa dapat meningkatkan aktivitas belajar dan memberikan respons yang positif terhadap pembelajaran, serta meningkatkan kemampuan numerasi siswa dalam menerapkan konsep matematika dalam kehidupan sehari-hari. Melalui modul numerasi ini pula diharapkan proses pembelajaran jarak jauh pada pembelajaran numerasi akan menjadi lebih baik.

Pembelajaran jarak jauh menggunakan modul numerasi dilakukan secara daring melalui media WhatsApp Group. Hal ini berdasarkan Atsani (2020) yang menyatakan bahwa dalam melaksanakan pembelajaran secara jarak jauh pendidik dapat menggunakan grup di media sosial salah satunya yaitu grup WhatsApp (WA) agar pendidik dapat memastikan bahwa peserta didik mengikuti pembelajaran dalam waktu yang bersamaan. Sehingga penggunaan modul numerasi serta kegiatan pembelajaran dapat terlaksana dengan baik.

\section{METODE PENELITIAN}

Penelitian dilakukan di kelas IV SD Islam Ma'arif 02 Terbanggi Besar pada semester ganjil Tahun Pelajaran 2020/2021. Penelitian ini merupakan penelitian pra eksperimen dengan tujuan untuk mencari efektivitas dari pembelajaran jarak jauh menggunakan modul numerasi pada masa pandemi covid-19 menggunakan desain the one shot case study. Menurut Ismail, (2018:53) pada desain ini terdapat satu kelas yang diberikan treatment atau perlakuan (X) dan selanjutnya dilakukan pengukuran $(\mathrm{O})$. pengukuran dilakukan dengan tujuan untuk mengetahui hasil setelah diberikan perlakuan. Dalam penelitian ini terdapat satu kelas yang diberikan treatment atau perlakuan berupa pembelajaran jarak jauh menggunakan modul numerasi dalam pembelajaran numerasi selanjutnya setelah dilaksanakan pembelajaran jarak jauh menggunakan modul numerasi dilakukan observasi untuk mengetahui efektivitas pembelajaran yang dilakukan.

Efektivitas pembelajaran jarak jauh menggunakan modul numerasi pada penelitian ini ditinjau dari empat indikator yaitu aktivitas siswa, respons siswa, 
hasil belajar numerasi siswa, dan keterlaksanaan pembelajaran numerasi pada materi luas persegi panjang yang terdapat di Tema 2 Sub Tema 3 di kelas IV semester ganjil. Sehingga variabel dalam penelitian ini adalah aktivitas siswa, respons siswa, hasil belajar numerasi siswa, dan keterlaksanaan pembelajaran numerasi pada Tema 2 Sub Tema 3 di kelas IV semester ganjil SDS Islam Ma'arif 02 Terbanggi Besar.

Aktivitas siswa dalam proses pembelajaran yaitu siswa menyelesaikan seluruh kegiatan yang ada di modul numerasi diantaranya kegiatan intuisi bilangan, konsep matematika, eksplorasi matematika, latihan, dan refleksi pembelajaran. Aktivitas siswa dalam proses pembelajaran dikatakan baik jika presentase siswa yang aktif selama proses pembelajaran mencapai $75 \%$. Presentase siswa yang aktif selama proses pembelajaran diperoleh melalui pemantauan lembar kerja peserta didik yang dikumpulkan setiap hari melalui WhatsApp. Untuk siswa yang tidak memiliki gawai, mengumpulkan pada saat kunjungan belajar ( home visit).

Respons siswa setelah pembelajaran numerasi yaitu tanggapan siswa terhadap pembelajaran yang dilaksanakan oleh guru melalui pembelajaran jarak jauh menggunakan modul numerasi. Respons siswa dikatakan baik apabila minimal $75 \%$ siswa yang memberi respons positif dari semua aspek yang ditanyakan pada angket respons siswa. Data respons siswa diperoleh dari lembar refleksi yang terdapat pada modul numerasi.

Hasil belajar numerasi adalah taraf kemampuan siswa dalam menyelesaikan permasalahan sehari-hari yang berkaitan dengan keliling dan luas persegi, persegi panjang, dan segitiga pada pembelajaran numerasi Tema 2 Sub Tema 3 yang diperoleh setelah proses pembelajaran yang ditandai dengan adanya perubahan sikap, perilaku sehingga memperoleh keterampilan dalam menyelesaikan permasalahan sehari-hari yang berkaitan dengan luas persegi panjang pada pembelajaran numerasi Tema 2 Sub Tema 3 dan diukur melalui tes, serta dituangkan dalam suatu angka berupa skor hasil belajar.

Keterlaksanaan pembelajaran yaitu keterlaksananaan setiap kegiatan pembelajaran yang sudah dituangkan dalam bentuk Rencana Pelaksanaan Pembelajaran (RPP) sehingga proses pembelajaran berjalan sesuai dengan rencana yang telah dibuat sebelumnya. Data skor keterlaksanaan pembelajaran diperoleh melalui lembar observasi keterlaksanaan pembelajaran yang disesuaikan dengan RPP. Data yang diperoleh dianalisis melalui pendekatan kuantitatif dengan menggunakan statistik deskriptif. Adapun teknik analisis data yang digunakan untuk masing-masing data yaitu sebagai berikut.

\section{a. Aktivitas siswa}

Data aktivitas siswa yang diperoleh melalui pengamatan yang dilakukan oleh dua orang pengamat yaitu peneliti dan guru kelas IV selama kegiatan pembelajaran berlangsung melalui grup WhatsApp. Kemudian data hasil pengamatan aktivitas siswa tersebut dianalisis dengan menggunakan presentase. Adapun presentase pengamaan aktivitas siswa yaitu sebagai berikut:

$$
\frac{\text { frekuensi setiap aspek pengamatan }}{\text { jumlah siswa }} \times 100 \%
$$


Kriteria keberhasilan aktivitas siswa dalam penelitian ini dikatakan efektif apabila minimal 70\% siswa terlibat aktif dalam proses pembelajaran.

b. Respons siswa

Data respons siswa yang diperoleh dari angket respons siswa terhadap kegiatan pembelajaran selanjutnya dianalisis dengan mencari presentase jawaban siswa untuk tiap-tiap pertanyaan dalam angket. Respons siswa dianalisis dengan melihat presentase dari respons siswa yang dihitung dengan menggunakan rumus sebagai berikut:

Keterangan :

$$
P R S=\frac{\text { jumlah skor seluruh aspek yang diperoleh }}{\text { jumlah skor maksimum seluruh aspek }} \times 100 \%
$$

PRS = persentase respons siswa

Kriteria keberhasilan respons siswa yaitu apabila siswa yang memberikan respons baik terhadapat pembelajaran paling sedikit $75 \%$.

c. Hasil Belajar Siswa

Hasil belajar siswa dianalisis dengan menggunakan analisis statistik deskriptif dengan tujuan mendeskripsikan pemahaman materi matematika siswa setelah menerapkan pembelajaran jarak jauh menggunakan modul numerasi. Kriteria yang digunakan untuk menentukan ketuntasan hasil belajar numerasi siswa kelas IV SD Islam Ma'arif 02 Terbanggi Besar dalam penelitian ini tersaji pada Tabel 1 berikut.

Tabel 1. Kategorisasi Standar Ketuntasan Hasil Belajar Matematika Siswa
\begin{tabular}{cc} 
Hasil Belajar & Kategorisasi Ketuntasan Belajar \\
\hline $0 \leq x<55$ & Tidak Tuntas \\
$55 \leq x \leq 100$ & Tuntas \\
\hline Sumber: SD Islam Ma'arif O2 Terbanggi Besar
\end{tabular}

d. Keterlaksanaan Pembelajaran

Untuk mengetahui apakah guru/peneliti sudah melaksanakan proses pembelajaran sesuai dengan Rencana Pelaksanaan Pembelajaran (RPP), maka dilakukan pengamatan keterlaksanaan pembelajaran yaitu dengan menggunakan lembar pengamatan keterlaksanaan pembelajaran dengan kriteria penskoran 1 sampai 4. Skor 4 diberikan jika guru/peneliti dalam melakukan pembelajaran dalam kategori sangat baik, skor 3 diberikan jika guru/peneliti dalam melakukan pembelajaran dalam kategori baik, skor 2 diberikan jika guru/peneliti dalam melakukan pembelajaran dalam kategori kurang, skor 1 diberikan jika guru/peneliti dalam melakukan pembelajaran dalam kategori sangat kurang. Dalam penelitian ini guru/peneliti dikatakan baik dalam melaksanakan pembelajaran jika perolehan skor akhir berada pada kategori baik atau sangat baik dengan kriteria pada Tabel 2 sebagai berikut.

Tabel 2. Konversi Nilai Tingkat Keterlaksanaan Pembelajaran

\begin{tabular}{cl}
\hline \multicolumn{1}{c}{ Interval Skor } & Kategori \\
\hline $3,50<\overline{\mathrm{X}} \leq 4,00$ & Sangat baik \\
$2,50<\overline{\mathrm{X}} \leq 3,49$ & Baik \\
$2,49<\overline{\mathrm{X}} \leq 1,50$ & Cukup baik \\
$1,49<\overline{\mathrm{X}} \leq 1,00$ & Kurang baik \\
\hline
\end{tabular}

Sumber : (Wahyuddin \& Nurcahaya, 2018) 


\section{HASIL DAN PEMBAHASAN}

Berdasarkan hasil penelitian yang dilakukan di SDS Islam Ma'arif 02 Terbanggi Besar penggunaan modul numerasi pada pembelajaran jarak jauh terhadap materi luas persegi panjang memperoleh proses pembelajaran dan hasil belajar numerasi siswa yaitu sebagai berikut.

a. Hasil Belajar

Berdasarkan hasil belajar siswa setelah diterapkan pembelajaran jarak jauh menggunakan modul numerasi melalui grup WhatsApp yang diperoleh melalui instrumen tes hasil belajar pada materi luas persegi panjang yaitu sebanyak 14 siswa telah mencapai KKM dan sebanyak 2 siswa belum mencapai KKM. Sehingga diperoleh persentase siswa yang telah mencapai kriteria ketuntasan minimum sebesar sebesar 87,5\%. Sebagaimana menurut Mulyasa (2014:131) "suatu pembelajaran yang dilihat dari hasil belajar dikatakan efektif jika hasil belajar siswa telah mencapai angka $\geq 75 \%$ dari jumlah siswa terhadap KKM". Sehingga pembelajaran jarak jauh menggunakan modul numerasi dikatakan efektif dilihat dari hasil belajar siswa.

b. Aktivitas Siswa

Aktivitas siswa dalam proses pembelajaran menggunakan modul numerasi diperoleh rata-rata persentase aktivitas siswa sebesar 87,5\%. Menurut Wahyuddin \& Nurcahaya (2018) kriteria keberhasilan aktivitas siswa dalam proses pembelajaran dikatakan efektif apabila minimal terdapat $70 \%$ siswa terlibat aktif dalam proses pembelajaran. Sehingga keberhasilan aktivitas siswa dalam pembelajaran jarak jauh menggunakan modul numerasi dikatakan berhasil dengan rata-rata persentase aktivitas siswa sebesar 87,5\%. Jadi, pembelajaran jarak jauh menggunakan modul numerasi dikatakan efektif dilihat dari aktivitas siswa.

\section{c. Respons Siswa}

Respons siswa terhadap pembelajaran jarak jauh menggunakan modul numerasi diperoleh $94,38 \%$ siswa memberikan respons positif. Sebagaimana menurut Wahyuddin \& Nurcahaya (2018) kriteria untuk menyatakan bahwa respons siswa terhadap pembelajaran adalah positif apabila minimal $75 \%$ siswa yang memberi respons positif dari semua aspek yang ditanyakan. Jadi pembelajaran jarak jauh menggunakan modul numerasi dikatakan efektif dilihat dari respons siswa terhadap pembelajaran.

d. Keterlaksanaan Pembelajaran

Keterlaksanaan pembelajaran jarak jauh menggunakan modul numerasi yang dilakukan oleh peneliti memperoleh skor 3,65 yang termasuk pada kategori sangat baik. Sebagaimana menurut Wahyuddin \& Nurcahaya (2018) kriteria keterlaksanaan pembelajaran dikatakan penerapannya baik apabila konversi nilai rata-rata setiap aspek pengamatan yang diberikan oleh pengamat pada setiap pertemuan berada pada kategori terlaksana atau sangat terlaksana agar pembelajaran dapat dikatakan efektif dilihat dari keterlaksanaan pembelajaran. Sehingga pembelajaran jauh menggunakan modul numerasi pada materi luas persegi panjang dikatakan efektif dilihat dari keterlaksanaan pembelajaran yang dilakukan.

Hal ini berarti keempat indikator efektivitas pembelajaran terpenuhi, sehingga pembelajaran menggunakan modul numerasi dikatakan efektif dan 
modul numerasi dapat membantu siswa dalam memahami materi pembelajaran dengan menyenangkan sehingga hasil belajar yang dicapai sangat baik serta memberikan arahan yang jelas dalam melaksanakan pembelajaran sehingga dapat meningkatkan aktivitas belajar siswa selama pembelajaran jarak jauh pada masa pandemi. Hal ini sesuai dengan hasil survey yang dilakukan oleh Puslitjak et al. (2020) yaitu dengan adanya modul belajar literasi dan numerasi, dapat memberikan arahan pembelajaran yang lebih jelas dan menurunkan beban belajar siswa dalam proses pembelajaran jarak jauh di rumah, selain itu dapat meningkatkan partisipasi belajar siswa dan meningkatkan kualitas pembelajaran selama pandemi.

\section{SIMPULAN}

Berdasarkan hasil analisis data dan pembahasan yang telah dikemukakan maka dapat diambil beberapa kesimpulan yaitu sebagai berikut: 1) terdapat $87,5 \%$ dari jumlah siswa yang memperoleh hasil belajar mencapai KKM; 2) ratarata persentase aktivitas siswa sebesar $87,5 \%$; 3) persentase respon siswa sebesar 94,38\% siswa memberikan respon positif; 4) hasil pengamatan keterlaksanaan pembelajaran diperoleh rata-rata skor sebesar 3,65. Berdasarkan empat kesimpulan diatas dapat disimpulkan kembali bahwa pembelajaran jarak jauh menggunakan modul numerasi pada materi luas persegi panjang di masa pandemi covid-19 efektif digunakan pada siswa kelas IV SD Islam Ma'arif 02 Terbanggi Besar semester ganjil tahun pelajaran $2020 / 2021$.

\section{DAFTAR PUSTAKA}

Atsani, L. G. M. Z. (2020). Transformasi media pembelajaran pada masa pandemi covid-19. Al-Hikmah: Jurnal Studi Islam, 1, 82-93.

Ismail, F. (2018). Statistika untuk Penelitian Pendidikan dan Ilmu-ilmu Sosial (M. Astuti (ed.); 1st ed.). Jakarta: Prenadamedia group

Mulyasa, E. 2014. Pengembangan dan Implementasi Kurikulum 2013. Bandung: PT Remaja Rosdakarya

Mulyasa, E., Dadang Iskandar, Wiwik Dyah Aryani. 2016. Revolusi dan Inovasi Pembelajaran. Bandung: PT Remaja Rosdakarya

Najuah, Lukityo, P. S., \& Wirianti, W. (2020). Modul Elektronik: Prosedur Penyusunan dan Aplikasinya (1st ed.). Yayasan Kita Menulis

Prawiradilaga, D. S., \& Chaeruman, U. A. (2018). Modul Hypercontent: Teknologi Kinerja (Performance Technology) (1st ed.). Kencana.

Puslitjak, Inovasi, Unicef, Foundation, T., \& save the children. (2020). Monitoring program kurikulum darurat dan modul belajar literasi dan numerasi (hasil survei guru). https://puslitjakdikbud.kemdikbud.go.id/assets_front/images/produk/1gtk/materi/1_Materi_Paparan_Meni_Handayani_10112020_Versi_2 
Siregar, Syofian. 2019. Statistik Parametrik Untuk Penelitian Kuantitatif. Jakarta: Bumi Aksara

Undang-undang Republik Indonesia Nomor 20 Tahun 2003 tentang Sistem Pendidikan Nasional.pdf

Uno, Hamzah B., Mohammad, Nurdin. 2014. Belajar dengan Pendekatan PAILKEM. Jakarta: Bumi Aksara

Wahyuddin \& Nurcahaya. (2018). Efektivitas pembelajaran matematika melalui pembelajaran aktif tipe everyone is a teacher here (eth) pada siswa kelas $\mathrm{X}$ SMA Negeri 8 Takalar. Al-Khawarizmi: Jurnal pendidikan dan Pembelajaran Matematika 2(1), 72-105. 